\title{
Babesiosis due to the canine Babesia microti-like small piroplasm in dogs - first report from Portugal and possible vertical transmission
}

\author{
Paula Brilhante Simões ${ }^{1 \dagger}$, Luís Cardoso ${ }^{2,3^{* \dagger}}$, Manuela Araújo ${ }^{1}$, Yael Yisaschar-Mekuzas ${ }^{4}$ and Gad Baneth ${ }^{4}$
}

\begin{abstract}
Background: Canine babesiosis (or piroplasmosis) is endemic in northern Portugal, but molecularly confirmed cases of infection with small piroplasms have not been reported in the country. Three German shepherd dogs a bitch and its 2-month old pup and an unrelated male - clinically suspected of piroplasmosis were assessed for babesial infection.

Results: Parasitemia with small piroplasms was detected by microscopy in two dogs. All three dogs were positive by PCR and the Babesia microti-like small piroplasm (syn. Theileria annae) was identified by DNA sequencing. These are the first confirmed cases of babesiosis caused by the B. microti-like piroplasm both in dogs from Portugal and in dogs suspected of clinical piroplasmosis outside of Spain.

Conclusions: Although the bitch and the male had visited neighboring Galicia (northwestern Spain), where the disease is endemic, incursion of this piroplasm into northern Portugal is evident and infection of the non-traveled pup was due to either vertical transmission or autochthonous tick infection.
\end{abstract}

\section{Background}

Species of protozoa from the Babesia and Theileria genera (order Piroplasmida) infect dogs in many parts of the world and cause important diseases known as babesiosis or piroplasmosis [1]. The etiological agents are transmitted by ixodid tick vectors [2], although transmission via blood transfusion [3] and the placenta [4] have been reported for some babesial species and dog to dog transmission of B. gibsoni by dog bites is strongly supported by epidemiological evidence [5-8]. Canine babesiosis may range from being sub-clinical to severe and fatal, depending on the virulence of the pathogen species or strain [9] and also on the susceptibility of the individual host as related to its age, immune status and concurrent infection or illness $[1,10]$. Lethargy, anorexia, pale mucous membranes, hyperthermia, hemoglobinuria, splenomegaly, hemolytic anemia and thrombocytopenia

\footnotetext{
* Correspondence: Icardoso@utad.pt

† Contributed equally

${ }^{2}$ Department of Veterinary Sciences, University of Trás-os-Montes e Alto

Douro, Vila Real, Portugal

Full list of author information is available at the end of the article
}

are clinical manifestations frequently described in dogs suffering from piroplasmosis $[11,12]$.

The size of their pear-shaped intraerythrocytic stages (piroplasms) has traditionally been used for the identification of Babesia species in dogs: large forms of Babesia canis $(3-5 \mu \mathrm{m})$ and small Babesia gibsoni $(0.5-2.5 \mu \mathrm{m})$. Additional criteria, especially molecular techniques, have further differentiated several "large" or "small" agents of canine piroplasmosis, including three subspecies of B. canis [13] currently regarded as separate species $[1,14,15]$ and one yet unnamed large Babesia sp. from North Carolina genetically related to Babesia bigemina of cattle [16,17]. Babesia canis is the main etiological agent in temperate regions of Europe and causes mild to severe disease [18]. Babesia vogeli, the least virulent subspecies, is also present in Europe [12] as well as in tropical or subtropical areas of Africa [19], Asia [20], Australia [21], and North and South America [6,22]. Babesia rossi, notoriously the most virulent subspecies, has been reported in western, eastern and southern Africa [23]. Babesia gibsoni is present in five continents $[1,6,11,20,24]$, including Europe [25-29]. Other genetically distinct small piroplasms capable of causing disease in dogs are Babesia conradae,
Ciomed Central

() 2011 Simões et al; licensee BioMed Central Ltd. This is an Open Access article distributed under the terms of the Creative Commons Attribution License (http://creativecommons.org/licenses/by/2.0), which permits unrestricted use, distribution, and reproduction in any medium, provided the original work is properly cited. 
from California [30], and the canine Babesia microti-like "Spanish isolate" or Theileria annae (phylogenetically close to zoonotic B. microti of humans). The latter is endemic in Galicia, northwestern Spain [31], but was also sporadically found in asymptomatic dogs from Croatia [28] and Mississippi [8].

The increased mobility of dogs may promote the circulation and exchange of vector-borne agents, including canine piroplasms, and their spread into geographical areas where they were previously not endemic [32]. Due to differences in the virulence of babesial species infecting dogs, information on the regional occurrence and prevalence of these agents is important for the diagnosis and management of individual clinical cases. Blood smear examination is useful to distinguish large from small intraerythrocytic piroplasms, but molecular diagnostic tools, such as the polymerase chain reaction (PCR) and DNA sequencing, are more sensitive methods that provide an accurate identification at the species, subspecies or genotype levels [20,33].

Canine babesiosis is endemic in northern Portugal. Ninety six per cent of the molecularly characterized cases of disease have been found infected with large B. canis and only $4 \%$ with B. vogeli $[34,35]$. However, confirmed cases of small piroplasms in dogs have not been reported in this country. The present study reports three cases of babesiosis in dogs from northern Portugal found infected with small piroplasms.

\section{Methods}

\section{Dogs and samples}

During 2009, blood samples were received at Inno laboratories, in the city of Braga, northwestern Portugal, from three German shepherd dogs clinically suspected of having piroplasmosis: a 4-year old bitch and a 1-year old male (October) and a 2-month female (November). Reported clinical signs included lethargy and pale mucous membranes for all the animals; anorexia for the bitch and the pup; and fever $\left(40^{\circ} \mathrm{C}\right)$ for the bitch. The three animals were from the same breeder. The pup had been born from the bitch in late September 2009 and never left Portugal. At the time samples were received, the bitch and pup still lived together, in the district of Braga, in an outdoor environment. Four other littermates had already been taken to other locations and were not available for medical examination. The male dog was also living in an outdoor environment in northwestern Portugal. In early August 2009 the bitch had been taken to Germany to mate and in the middle of that month, on its way back to northwestern Portugal, it was housed for 10 days in a kennel in Vigo, Galicia (northwestern Spain). The male dog had also been housed in the same kennel in Vigo, approximately at the same time. The bitch had been found infested with ticks, whose species was not identified, in the second half of August 2009, after returning to Portugal; the pup never had detectable ticks; and no information on the presence of ticks could be retrieved regarding the male dog.

Blood in EDTA was used to prepare thin glass-slide smears that were air-dried, fixed with methanol, stained with Hemacolor ${ }^{\circledR}$ (Merck, Germany) and then examined under light microscopy (magnification of $1000 \times$ ) for the detection of possible piroplasms. Blood was also spotted onto individual papers $(7.5 \mathrm{~cm} \times 2.5 \mathrm{~cm}$; GB 002 Schleicher and Schuell, Dassel, Germany) allowed to air-dry and stored at $-20^{\circ} \mathrm{C}$ until further use.

A complete blood count (CBC) was performed for all the dogs and repeated $C B C$ was carried out for the bitch two days (day 2) and six days (day 6) after the primary assessment (day 0). A reticulocyte count was done for the bitch on day 2 using new methylene blue (Sigma-Aldrich, UK), as described by Tvedten and Weiss [36]. An additional determination of serum biochemical parameters (total protein, albumin, globulins, urea, creatinine, total bilirubin, glucose, alanine transaminase and alkaline phosphatase) was done on day 0 from the bitch's serum (Prestige 24i; Cormay, Tokyo Boeki Medical System, Japan).

\section{DNA extraction, PCR and sequence analysis}

DNA was extracted from filter papers as previously described [35]. Primers Piro-A (5'-AAT ACC CAA TCC TGACAC AGG G-3') and Piro-B (5'-TTA AAT ACG AAT GCC CCC AAC-3') were used to amplify a 408 bp fragment of the 18S rRNA gene of Babesia spp. by PCR [37]. Amplification was done under the following conditions: $94^{\circ} \mathrm{C}$ for $1 \mathrm{~min}$ followed by 39 cycles of $94^{\circ} \mathrm{C}$ for $45 \mathrm{~s}, 62^{\circ} \mathrm{C}$ for $45 \mathrm{~s}$, and $72^{\circ} \mathrm{C}$ for $45 \mathrm{~s}$. DNA sequencing was performed at the Center for Genomics Technologies, Hebrew University of Jerusalem. Obtained DNA sequences were evaluated with the ChromasPro software version 1.33 and compared for similarity to sequences in GenBank, using the BLAST program hosted by NCBI, National Institutes of Health, USA http://www.ncbi.nlm. nih.gov.

\section{Results}

Intraerythrocytic isolated ring-shaped bodies morphologically compatible with small piroplasms were detected by microscopy in blood smears from the bitch and the pup (Figure 1) but not from the male. Table 1 summarizes hematological results from the three animals. The bitch primarily had a hypochromic normocytic anemia at day 0 that changed to hypochromic macrocytic on day 2. An increasing level of polychromasia was evident in the blood smear at days $0(1+), 2(3+)$ and $6(4+)$, as well as other hematological findings compatible with 


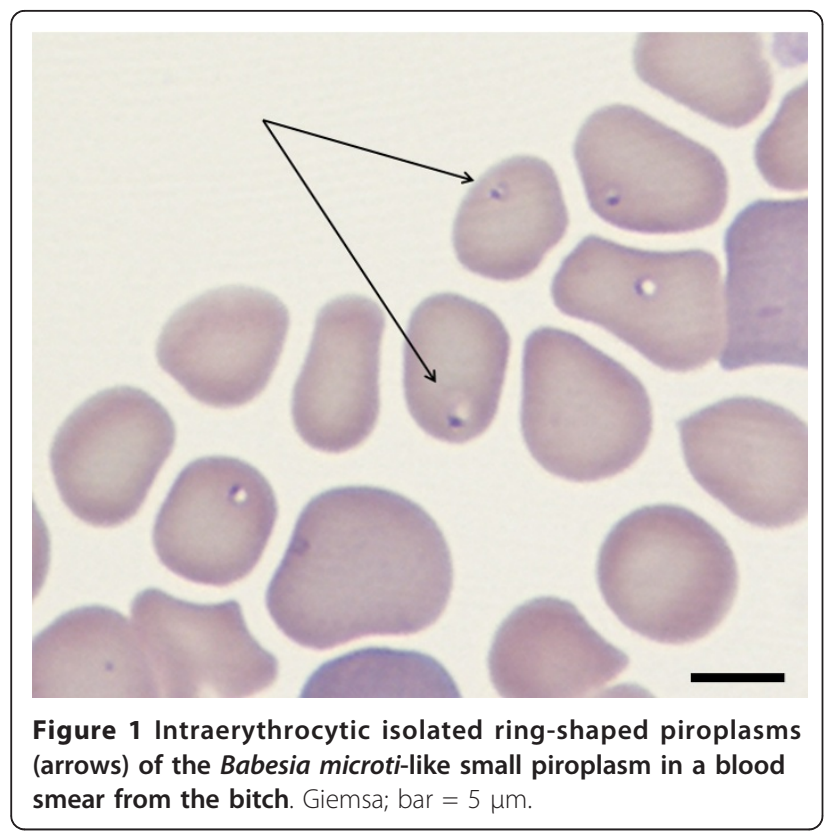

regenerative anemia, i.e. anisocytosis, metarubricytes and Howell-Jolly bodies. A count of $1 \times 10^{5}$ reticulocytes $/ \mu \mathrm{l}$ on day 2 (regarded as a mild to moderate increase, which is compatible with $6 \times 10^{4}$ to $2 \times 10^{5}$ reticulocytes $/ \mu \mathrm{l}$ ), further confirmed regenerative anemia. Toxic neutrophils (10-30\%), at days 0 and 2, exhibiting Döhle bodies and cytoplasmic basophilia and vacuolization, and reactive lymphocytes were also observed. Thrombocytopenia was also present and changed from severe at day 0 to mild at day 6. Macroplatelets could be detected, at days 0 and 2, suggesting increased bone marrow megakaryocytic activity. On the biochemical profile, bilirubin concentration was mildly elevated at $0.63 \mathrm{mg} / \mathrm{dl}$ (normal range: $0-0.3$ ). Results for the other measured parameters were within normal limits.

The male dog presented a moderate hypochromic macrocytic anemia, with findings typical of red blood cells (RBC) regeneration, i.e. polychromasia, $81 \%$ of nucleated RBC (metarubricytes and rubricytes) and anisocytosis. Mild leukocytosis $\left(23.1 \times 10^{3}\right.$ cells/ $\mu$ l) was noted, with mild neutrophilia and severe lymphocytosis. Platelet count could not be done, due to the existence of platelet aggregates, which were detected by blood smear observation.

The pup had severe hypochromic normocytic anemia with polychromasia and anisocytosis. Moderate to severe leukopenia with a degenerative left shift and more than $30 \%$ of toxic neutrophils exhibiting Döhle bodies, cytoplasmic basophilia and vacuolization, and reactive lymphocytes were found. Severe thrombocytopenia as well as macroplatelets were observed.

The three animals were all found positive for Babesia spp. by the PCR assay. Further sequence analysis revealed that the bitch and male yielded an identical 414 bp long sequence that was 409/414 (98\%) identical to the GenBank closest sequence EU583387.1, the canine small Babesia "Spanish isolate" or B. microti-like piroplasm. The pup yielded a $413 \mathrm{bp}$ sequence that was 409/413 (99\%) identical to GenBank EU583387.1 and 99\% identical to the bitch and male sequence.

Imidocarb dipropionate $(6 \mathrm{mg} / \mathrm{kg}$, subcutaneous injection, repeated 14 days later) was used to treat the bitch (on day 1), the male and the pup. Available information

Table 1 Results from hematological analyses of the three dogs with babesiosis due to the Babesia microti-like piroplasm

\begin{tabular}{|c|c|c|c|c|c|c|}
\hline \multirow[t]{2}{*}{ Parameter } & \multicolumn{3}{|l|}{ Bitch } & \multirow{2}{*}{$\begin{array}{l}\text { Male } \\
\text { Day } 0\end{array}$} & \multirow{2}{*}{$\begin{array}{l}\text { Pup } \\
\text { Day } 0\end{array}$} & \multirow[t]{2}{*}{ Normal range } \\
\hline & Day 0 & Day 2 & Day 6 & & & \\
\hline $\mathrm{RBC}\left(10^{6} / \mu \mathrm{l}\right)$ & 2.4 & 1.9 & 2.3 & 2.8 & 1.3 & $5.5-8.5$ \\
\hline $\mathrm{Hb}(\mathrm{g} / \mathrm{dl})$ & 5.4 & 4.6 & 5.7 & 7.4 & 2.5 & $12-18$ \\
\hline Hct (\%) & 17.9 & 17.0 & 20.6 & 26.7 & 8.2 & $37-55$ \\
\hline $\mathrm{MCV}(\mathrm{fl})$ & 73.7 & 88.1 & 88.4 & 95.9 & 66.0 & $60-74$ \\
\hline $\mathrm{MCHC}(\mathrm{g} / \mathrm{dl})$ & 30.2 & 27.1 & 27.7 & 27.8 & 30.5 & $31-36$ \\
\hline RDW (\%) & 16.5 & 16.5 & 16.4 & 20.6 & 21.0 & $12-18$ \\
\hline Nucleated RBC (\%) & ND & 15.0 & 22.0 & 81.0 & ND & $<3$ \\
\hline WBC $\left(10^{3} / \mu \mathrm{l}\right)$ & 10.8 & $14.0^{*}$ & $7.8^{*}$ & $23.1^{*}$ & 2.8 & $6-17$ \\
\hline Segmented neutrophils $\left(10^{3} / \mu \mathrm{l}\right)$ & 7.8 & 10.4 & 5.4 & 13.6 & 0.8 & $3-11.8$ \\
\hline Band neutrophils $\left(10^{3} / \mu \mathrm{l}\right)$ & 0.0 & 0.0 & 0.0 & 0.0 & 0.6 & $0-0.5$ \\
\hline Lymphocytes $\left(10^{3} / \mu \mathrm{l}\right)$ & 2.1 & 1.8 & 1.9 & 8.3 & 1.2 & $1-4.8$ \\
\hline Monocytes $\left(10^{3} / \mu \mathrm{l}\right)$ & 1.0 & 1.7 & 1.1 & 1.4 & 0.2 & $0.2-2$ \\
\hline Eosinophils $\left(10^{3} / \mu \mathrm{l}\right)$ & 0.0 & 0.0 & 0.2 & 0.0 & 0.0 & $0.1-1.3$ \\
\hline Platelets $\left(10^{3} / \mu \mathrm{l}\right)$ & 19 & 63 & 165 & $N D^{* *}$ & 54 & $200-500$ \\
\hline
\end{tabular}

Hb: hemoglobin; Hct: hematocrit; MCHC: mean corpuscular hemoglobin concentration; MCV: mean corpuscular volume; ND: not determined; RBC: red blood cells; RDW: red blood cell distribution width; WBC: white blood cells; * WBC count corrected for the presence of nucleated RBC; ${ }^{* *}$ platelet aggregates hindered platelet count. 
suggested an apparent clinical recovery of the three dogs; however, the pup died in December 2009 due to parvoviral enteritis.

\section{Discussion}

To the best of our knowledge, this is the first report of molecular identification of the B. microti-like piroplasm both in dogs from Portugal and in dogs suspected of clinical piroplasmosis outside of Spain.

The designation $B$. microti-like piroplasm has been used in the present description, as genetic analyses revealed that $T$. annae [38] is more closely related to B. microti, a rodent piroplasm that causes babesiosis in humans, than to other Theileria spp. $[8,39,40]$. Furthermore, no evidence has been presented for pre-erythrocytic stages of this infection in leukocytes, which is a characteristic of the theilerial life cycle [41]. The name "Spanish isolate" also used to describe this pathogen [8] comes from the first description of this causative agent, which was made from a dog with piroplasmosis (originated from a Babesia-free area in Germany) that had travelled to northeastern Spain [38].

The B. microti-like piroplasm can cause severe disease and mortality in dogs and is endemic in Galicia, northwestern Spain $[31,39]$, which northerly borders the area where the three dogs from the present report lived in Portugal. According to the published information, the $B$. microti-like piroplasm had been molecularly sequenced from dogs with clinical babesiosis only from Spain and mostly from Galicia [31,39,42]. Besides, there are reports of infection in a few clinically healthy dogs: one from Tarragona, northeastern Spain [43], another one from Croatia [28] and an additional one from Mississipi [8]. DNA of the B. microti-like piroplasm has also been detected in foxes from central and northern Spain [44-46], eastern Canada, North Carolina in the USA [47], Croatia [48]; in cats from Portugal [49] and Italy [50]; in a donkey from northern Spain [51]; in roe deer from Italy [52]; in feral raccoons from Japan [53]; in Ixodes ricinus and Rhipicephalus sanguineus ticks from Italy [54,55]; and in I. ricinus and Ixodes hexagonus from northern Spain [46]. To date, this piroplasm species has not been reported in Africa or Australia.

Ixodes hexagonus is the main candidate vector of the B. microti-like piroplasm in Galicia [56]. This tick species has also been found in northern Portugal [57,58], but the endemic nature of the small piroplasm in this area cannot be ascertained. In the present report, the bitch and the male dog were most probably infected during the 10day period they spend in Vigo (Galicia), although the possibility that the infection originated in Portugal should not be excluded. Both dogs became clinically suspected two months after returning from Vigo. This fact suggests a longer incubation period for the disease caused by the
B. microti-like piroplasm in comparison with the 4 to 21 days described for other canine babesial infections [2]. However, the pup never left Portugal and could have been infected by vertical transmission. The transplacental transmission of $B$. gibsoni has been experimentally demonstrated in a bitch that delivered a litter of one stillborn and four live pups [4]. These four pups died from congenital babesiosis between 14 and 39 days post-birth.

In horses, once an animal is infected with T. equi it remains a lifelong carrier, since anti-theilerial drugs do not completely eliminate the parasite [59]. Infected mares can transmit T. equi piroplasms across the placenta and this might result in abortion or neonatal piroplasmosis. Colostral antibodies to T. equi may suppress parasitaemia in newborn foals thereby reducing the incidence of clinical neonatal equine piroplasmosis, which could control parasitaemia during the foals' early months of life [59]. In the present report, a more than 2 -month time interval between possible infection in utero and clinical disease might be explained by a similar protection conferred on the pup by maternal colostrum. Nevertheless, and although it had no detectable ticks, the possibility that the pup was infected after birth by a tick vector cannot be ruled out.

A severe regenerative haemolytic anemia and moderate to severe thrombocytopenia are common findings among dogs infected with the $B$. microti-like piroplasm $[60,61]$. In the present report, the three dogs had regenerative anaemia, based on reticulocyte count (performed only for the bitch), presence of polychromasia, anisocytosis and nucleated RBC. The mechanisms related with severe hemolytic anemia may be more dependent on the host immune response than on the direct destruction of RBC by the piroplasm [2]. The bitch and pup also had confirmed severe thrombocytopenia, while platelet count could not be assessed in the male dog. Mechanisms of local or systemic intravascular coagulopathy, immune-mediated destruction or splenic sequestration may be implicated in severe thrombocytopenias. On the other hand, the almost constant presence of macroplatelets in blood smears is associated with a bone marrow regenerative response to platelet consumption, as well as sequestration or destruction [2].

The bitch had normal leukocyte counts, while the male dog presented leukocytosis and the pup had leukopenia. Camacho-García [31] describes that half the dogs with piroplasmosis due to the B. microti-like piroplasm had normal leukocyte counts. Nevertheless, the values may range between leukopenia and leukocytosis, with the latter reaching extreme counts compatible with a leukemoid response in immune-mediated hemolytic anemia [60]. Many cases also develop serum biochemistry abnormalities compatible with a glomerular component of renal failure [31]. In a study describing 58 
infected dogs, 36\% were azotemic at the time of diagnosis and $22 \%$ died with azotemia being the main cause of mortality [62]. In the present report, serum creatinine and urea were assessed only for the bitch and found to be within their normal range.

According to Camacho-García [31], animals infected with the $B$. microti-like piroplasm had a syndrome clinically more severe than those infected with B. canis, treatment with imidocarb dipropionate was less effective and evolution towards renal failure more frequent. At the time the pup died from parvoviral enteritis, one month after diagnosis of babesial infection, it had apparently recovered from the clinical disease caused by the small piroplasm.

The definitive diagnosis of babesiosis for the male dog was achieved only after the PCR and sequencing results. Indeed, in dogs clinically suspected of babesiosis, microscopy may lack sensitivity due to low parasitaemia [1]. Sensitive molecular detection and species identification are important for the selection of the appropriate therapy and for prognosis, as well as for the screening of subclinical infections and blood donors [29].

\section{Conclusions}

This study reports the first confirmed cases of canine babesiosis caused by the $B$. microti-like piroplasm in Portugal involving two adult dogs and a pup. Although the two adult dogs may have been infected in the neighboring Spanish province of Galicia, incursion of this infection into northern Portugal where possible suitable tick vectors are present is evident. Infection of the nontraveled pup was due to either vertical transmission or autochthonous tick infection. Awareness of the risk of spread of the B. microti-like piroplasm to additional countries via dog travel or infected vector transport should be increased and efforts to prevent further spread of this infection are warranted.

\section{Acknowledgements}

The authors thank Dr. Augusto Silva from Inno laboratories for his assistance. Publication of the CVBD6 thematic series has been sponsored by Bayer Animal Health $\mathrm{GmbH}$.

\section{Author details}

${ }^{1}$ Inno - Serviços Especializados em Veterinária, Braga, Portugal. ${ }^{2}$ Department of Veterinary Sciences, University of Trás-os-Montes e Alto Douro, Vila Real, Portugal. ${ }^{3}$ Parasite Disease Group, Instituto de Biologia Molecular e Celular, Universidade do Porto, Portugal. ${ }^{4}$ School of Veterinary Medicine, Hebrew University of Jerusalem, Rehovot, Israel.

\section{Authors' contributions}

Conceived and designed the study: LC and GB. Collected and characterized clinical samples: PBS and MA. Performed PCR and genetic analysis: YYM and GB. Analyzed data, drafted and revised the manuscript: PBS, LC and GB. All authors gave final approval of the version to be submitted.

\section{Competing interests}

The authors declare that they have no competing interests.
Received: 25 November 2010 Accepted: 13 April 2011

Published: 13 April 2011

\section{References}

1. Irwin P: Canine babesiosis: from molecular taxonomy to control. Parasites Vect 2009, 2(Suppl 1):S4

2. Boozer AL, Macintire DK: Canine babesiosis. Vet Clin Small Anim 2003, 33:885-904.

3. Stegeman JR, Birkenheuer AJ, Kruger JM, Breitschwerdt EB: Transfusionassociated Babesia gibsoni infection in a dog. J Am Vet Med Assoc 2003, 222:959-963.

4. Fukumoto S, Suzuki $H$, lgarashi I, Xuan X: Fatal experimental transplacental Babesia gibsoni infections in dogs. Int J Parasitol 2005, 35:1031-1035.

5. Matsuu A, Kawabe A, Koshida Y, Ikadai H, Okano S, Higuchi S: Incidence of canine Babesia gibsoni infection and subclinical infection among Tosa dogs in Aomori Prefecture, Japan. Journal Vet Med Sci 2004, 66:893-897.

6. Birkenheuer AJ, Correa MT, Levy MG, Breitschwerdt EB: Geographic distribution of babesiosis among dogs in the United States and association with dog bites: 150 cases (2000-2003). J Am Vet Med Assoc 2005, 227:942-947

7. Jefferies R, Ryan UM, Jardine J, Broughton DK, Robertson ID, Irwin PJ: Blood, Bull Terriers and Babesiosis: further evidence for direct transmission of Babesia gibsoni in dogs. Aust Vet J 2007, 85:459-463.

8. Yeagley TJ, Reichard MV, Hempstead JE, Allen KE, Parsons LM, White MA, Little SE, Meinkoth $\mathrm{JH}$ : Detection of Babesia gibsoni and the canine small Babesia 'Spanish isolate' in blood samples obtained from dogs confiscated from dogfighting operations. J Am Vet Med Assoc 2009, 235:535-539.

9. Schetters TMP, Moubri K, Précigout E, Kleuskens J, Scholtes NC, Gorenflot A: Different Babesia canis isolates, different diseases. Parasitology 1997, 115:485-493.

10. Brandão LP, Hagiwara MK, Myiashiro SI: Humoral immunity and reinfection resistance in dogs experimentally inoculated with Babesia canis and either treated or untreated with imidocarb dipropionate. Vet Parasitol 2003, 114:253-265.

11. Lobetti RG: Canine babesiosis. Compend Cont Educ Pract Vet 1998, 20:418-431.

12. Solano-Gallego L, Trotta M, Carli E, Carcy B, Caldin M, Furlanello T: Babesia canis canis and Babesia canis vogeli clinicopathological findings and DNA detection by means of PCR-RFLP in blood from Italian dogs suspected of tick-borne disease. Vet Parasitol 2008, 157:211-221.

13. Uilenberg G, Franssen FFJ, Perie M, Spanjer AMM: Three groups of Babesia canis distinguished and a proposal for nomenclature. Vet Q 1989, 11:33-40.

14. Zahler M, Schein E, Rinder H, Gothe R: Characteristic genotypes discriminate between Babesia canis isolates of differing vector specificity and pathogenicity to dogs. Parasitol Res 1998, 84:544-548.

15. Carret C, Walas F, Carcy B, Grande N, Précigout E, Moubri K, Schetters TP, Gorenflot A: Babesia canis canis, Babesia canis vogeli, Babesia canis rossi: differentiation of the three subspecies by a restriction fragment length polymorphism analysis on amplified small subunit ribosomal RNA genes. J Eukaryot Microbiol 1999, 46:298-303.

16. Birkenheuer AJ, Neel J, Ruslander D, Levy MG, Breitschwerdt EB: Detection and molecular characterization of a novel large Babesia species in a dog. Vet Parasitol 2004, 124:151-160.

17. Sikorski LE, Birkenheuer AJ, Holowaychuk MK, McCleary-Wheeler AL, Davis JM, Littman MP: Babesiosis caused by a large Babesia species in 7 immunocompromised dogs. J Vet Intern Med 2010, 24:127-131.

18. Cacciò SM, Antunovic B, Moretti A, Mangili V, Marinculic A, Baric RR, Slemenda SB, Pieniazek NJ: Molecular characterisation of Babesia canis canis and Babesia canis vogeli from naturally infected European dogs. Vet Parasitol 2002, 106:285-292.

19. Matjila TP, Penzhorn BL, Bekker CPJ, Nijhof AM, Jongejan F: Confirmation of occurrence of Babesia canis vogeli in domestic dogs in South Africa. Vet Parasitol 2004, 122:119-125.

20. Inokuma H, Yoshizaki Y, Matsumoto K, Okuda M, Onishi T, Nakagome K, Kosugi R, Hirakawa M: Molecular survey of Babesia infection in dogs in Okinawa, Japan. Vet Parasitol 2004, 121:341-346.

21. Jefferies R, Ryan UM, Muhlnickel CJ, Irwin PJ: Two species of canine Babesia in Australia: detection and characterization by PCR. J Parasitol 2003, 89:409-412. 
22. Passos LMF, Geiger SM, Ribeiro MFB, Pfister K, Zahler-Rinder M: First molecular detection of Babesia vogeli in dogs from Brazil. Vet Parasitol 2005, 127:81-85.

23. Sasaki M, Omobowale O, Tozuka M, Ohta K, Matsuu A, Nottidge HO, Hirata H, Ikadai H, Oyamada T: Molecular survey of Babesia canis in dogs in Nigeria. J Vet Med Sci 2007, 69:1191-1193.

24. Muhlnickel CJ, Jefferies R, Morgan-Ryan UM, Irwin PJ: Babesia gibsoni infection in three dogs in Victoria. Aust Vet J 2002, 80:606-610.

25. Suarez ML, Espino L, Goicoa Fidalgo LE, Santamarina G: Fatal Babesia gibsoni infection in a dog from Spain. Vet Rec 2001, 148:819-820.

26. Criado-Fornelio A, Gónzalez-del-Río MA, Buling-Saraña A, Barba-Carretero JC: Molecular characterization of a Babesia gibsoni isolate from a Spanish dog. Vet Parasitol 2003, 117:123-129.

27. Hartelt K, Rieker T, Oehme RM, Brockmann SO, Müller W, Dorn N: First evidence of Babesia gibsoni (Asian genotype) in dogs in Western Europe. Vector Borne Zoonotic Dis 2007, 7:163-166.

28. Beck R, Vojta L, Mrljak V, Marinculić A, Beck A, Živičnjak T, Cacciò SM: Diversity of Babesia and Theileria species in symptomatic and asymptomatic dogs in Croatia. Int J Parasitol 2009, 39:843-848.

29. Trotta M, Carli E, Novari G, Furlanello T, Solano-Gallego L:

Clinicopathological findings, molecular detection and characterization of Babesia gibsoni infection in a sick dog from Italy. Vet Parasitol 2009, 165:318-322

30. Kjemtrup AM, Wainwright K, Miller M, Penzhorn BL, Carreno RA: Babesia conradae, sp. Nov., a small canine Babesia identified in California. Vet Parasitol 2006, 138:103-111.

31. Camacho-García AT: Piroplasma infection in dogs in northern Spain. Vet Parasitol 2006, 138:97-102.

32. Cardoso L: Dogs, arthropod-transmitted pathogens and zoonotic diseases. Trends Parasitol 2010, 26:61-62

33. Jefferies R, Ryan UM, Irwin PJ: PCR-RFLP for the detection and differentiation of the canine piroplasm species and its use with filter paper-based technologies. Vet Parasitol 2007, 144:20-27.

34. Cardoso L, Costa A, Tuna J, Vieira L, Eyal O, Yisaschar-Mekuzas Y, Baneth G: Babesia canis canis and Babesia canis vogeli infections in dogs from northern Portugal. Vet Parasitol 2008, 156:199-204

35. Cardoso L, Yisaschar-Mekuzas Y, Rodrigues FT, Costa A, Machado J, DizLopes D, Baneth G: Canine babesiosis in northern Portugal and molecular characterization of vector-borne co-infections. Parasites Vect 2010, 3:27.

36. Tvedten H, Weiss D: Erythrocyte disorders. In Small Animal Clinical Diagnosis by Laboratory Methods.. 3 edition. Edited by: Willard M, Tvedten H, Turnwald G. St Louis: WB Saunders; 1999:31-51.

37. Olmeda AS, Armstrong PM, Rosenthal BM, Valladares B, del Castillo A, de Armas F, Miguelez M, Gonzalez A, Rodriguez JA, Spielman A, Telford SR: A subtropical case of human babesiosis. Acta Trop 1997, 67:229-234.

38. Zahler M, Rinder $H$, Schein E, Gothe R: Detection of a new pathogenic Babesia microti-like species in dogs. Vet Parasitol 2000, 89:241-248.

39. Camacho AT, Pallas E, Gestal JJ, Guitián FJ, Olmeda AS, Goethert HK, Telford SR: Infection of dogs in northwest Spain with a Babesia microtilike agent. Vet Rec 2001, 149:552-555.

40. Reichard MV, Van Den Bussche RA, Meinkoth JH, Hoover JP, Kocan AA: A new species of Cytauxzoon from Pallas' cats caught in Mongolia and comments on the systematics and taxonomy of piroplasmids. J Parasitol 2005, 91:420-426.

41. Goethert HK, Telford SR III: What is Babesia microti? Parasitology 2003, 127:301-309.

42. Criado A, Martinez J, Buling A, Barba JC, Merino S, Jefferies R, Irwin PJ: New data on epizootiology and genetics of piroplasms based on sequences of small ribosomal subunit and cytochrome b genes. Vet Parasitol 2006, 142:238-247

43. Tabar MD, Francino $O$, Altet $L$, Sánchez $A$, Ferrer $L$, Roura $X$ : PCR survey of vectorborne pathogens in dogs living in and around Barcelona, an area endemic for leishmaniosis. Vet Rec 2009, 164:112-116.

44. Criado-Fornelio A, Martinez-Marcos A, Buling-Saraña A, Barba-Carretero JC: Molecular studies on Babesia, Theileria and Hepatozoon in southern Europe. Part I. Epizootiological aspects. Vet Parasitol 2003, 113:189-201.

45. Criado-Fornelio A, Rey-Valeiron C, Buling A, Barba-Carretero JC, Jefferies R, Irwin P: New advances in molecular epizootiology of canine hematic protozoa from Venezuela, Thailand and Spain. Vet Parasitol 2007, 144:261-269.
46. Lledó L, Giménez-Pardo C, Domínguez-Peñafiel G, Sousa R, Gegúndez MI, Casado N, Criado A: Molecular detection of hemoprotozoa and Rickettsia species in arthropods collected from wild animals in the Burgos Province, Spain. VectorBorne Zoonotic Dis 2010, 10:735-738.

47. Birkenheuer AJ, Horney B, Bailey M, Scott M, Sherbert B, Catto V, Marr HS, Camacho AT, Ballman AE: Babesia microti-like infections are prevalent in North American foxes. Vet Parasitol 2010, 172:179-182.

48. Dezdek D, Vojta L, Curković S, Lipej Z, Mihaljević Z, Cvetnić Z, Beck R: Molecular detection of Theileria annae and Hepatozoon canis in foxes (Vulpes vulpes) in Croatia. Vet Parasitol 2010, 172:333-336.

49. Criado-Fornelio A, Martinez-Marcos A, Buling-Saraña A, Barba-Carretero JC: Presence of Mycoplasma haemofelis, Mycoplasma haemominutum and piroplasmids in cats from southern Europe: a molecular study. Vet Microbiol 2003, 93:307-317.

50. Pennisi MG, Alongi A, Agnone A, Vitale F, Reale S, Torina A: Cats as reservoir of Babesia microti. Parassitologia 2007, 49(Suppl 1):100.

51. Gimenez C, Casado N, Criado-Fornelio A, de Miguel FA, DominguezPeñafiel G: A molecular survey of Piroplasmida and Hepatozoon isolated from domestic and wild animals in Burgos (northern Spain). Vet Parasitol 2009, 26:147-150.

52. Tampieri MP, Galuppi R, Bonoli C, Cancrini G, Moretti A, Pietrobelli M: Wild ungulates as Babesia hosts in Northern and Central Italy. Vector Borne Zoonotic Dis 2008, 8:667-674.

53. Kawabuchi T, Tsuji M, Sado A, Matoba Y, Asakawa M, Ishihara C: Babesia microti-like parasites detected in feral raccoons (Procyon lotor) captured in Hokkaido, Japan. J Vet Med Sci 2005, 67:825-827.

54. Cassini R, Zanutto S, Frangipane del Rogalbono A, Gabrielli S, Calderini P, Moretti A, Tampieri MP, Pietrobelli M: Canine piroplasmosis in Italy: epidemiological aspects in vertebrate and invertebrate hosts. Vet Parasitol 2009, 165:30-35.

55. Iori A, Gabrielli S, Calderini P, Moretti A, Pietrobelli M, Tampieri MP, Galuppi R, Cancrini G: Tick reservoirs for piroplasms in central and northern Italy. Vet Parasitol 2010, 170:291-296

56. Camacho AT, Pallas E, Gestal JJ, Guitián FJ, Olmeda AS, Telford SR III, Spielman A: Ixodes hexagonus is the main candidate as vector of Theileria annae in northwest Spain. Vet Parasitol 2003, 112:157-163.

57. Caeiro VMP: As carraças em Portugal: seus hospedeiros domésticos e silvestres. Ciclos vitais, preferências de vegetação e clima. Med Vet 1992, 28:7-25.

58. Caeiro V: General review of tick species present in Portugal. Parassitologia 1999, 41(Suppl 1):11-15.

59. Allsopp MTEP, Lewis BD, Penzhorn BL: Molecular evidence for transplacental transmission of Theileria equi from carrier mares to their apparently healthy foals. Vet Parasitol 2007, 148:130-136

60. Guitián FJ, Camacho AT, Telford SR III: Case-control study of canine infection by a newly recognised Babesia microti-like piroplasm. Prev Vet Med 2003, 61:137-145.

61. Camacho AT, Guitian FJ, Pallas E, Gestal JJ, Olmeda AS, Goethert HK, Telford SR III, Spielman A: Serum protein response and renal failure in canine Babesia annae infection. Vet Res 2005, 36:713-722.

62. Camacho AT, Guitian FJ, Pallas E, Gestal JJ, Olmeda AS, Goethert HK, Telford SR III, Spielman A: Azotemia and mortality among Babesia microtilike infected dogs. J Vet Intern Med 2004, 18:141-146.

doi:10.1186/1756-3305-4-50

Cite this article as: Simões et al:: Babesiosis due to the canine Babesia microti-like small piroplasm in dogs - first report from Portugal and possible vertical transmission. Parasites \& Vectors 2011 4:50. 